\title{
Vještica kao anti-majka: psihoanalitička interpretacija zapisnika sa suđenja
}

\author{
NATAŠA POLGAR \\ Institut za etnologiju i folkloristiku, Zagreb
}

\begin{abstract}
U tekstu se na osnovi zapisnika sa suđenja vješticama u sjeverozapadnoj Hrvatskoj od kraja 17. pa do sredine 18. stoljeća ukazuje na njihovu zajedničku neuralgičnu točku, a to je odnos prema tijelu i tjelesnosti. Analizom iskaza sa suđenja, kojima se pristupa kao osobnim narativima žena o njihovim životima, strahovima, projekcijama pa i fantazmama, moguće je iščitati da anksioznost povezana s manifestacijama tijela ima svoje izvorište u psihičkome strukturiranju subjektiviteta. Određeni elementi vještičjega imaginarija poput infanticida i antropofagije govore o strahu od majke koja subjektu priječi ulazak u prostor simboličkog, odnosno ukazuju na svojevrsnu zaglavljenost u liminalnom području između imaginarnoga i simboličkoga. Majka kao subjektov Drugi koji mu jamči život i identitet premeće se potkraj 17. stoljeća u monstruoznu vješticu koja prijeti poništavanjem cijele "ženske" domene - djece, doma, hrane, životinja, ali koja postaje i kolektivnim Drugim koji je poslužio za kanaliziranje sukoba, tjeskoba i nasilja u društvu.
\end{abstract}

Ključne riječi: vještice, kontinentalna Hrvatska, Lacan, psihoanalitička kritika, Drugi, antropofagija, infanticid, tijelo

Vjerovanja u vještice, zle sile i čarobnjake/čarobnice vjerojatno su stara koliko i ljudski rod - njihove tragove pronalazimo još od antike pa sve do suvremenosti, u književnosti, ali i u izvanknjiževnoj stvarnosti. No predodžbe o vješticama se tijekom stoljeća mijenjaju, podjednako u pravnim dokumentima, zakonima i propisima, kao i u književnosti te drugim umjetnostima, ponajprije vizualnima. Hekata, troglava boginja (ponegdje prikazana i s tri tijela) i zaštitnica svih čarobnica, te njezine nasljednice - kćeri, nećakinje i unuke - Medeja, Kirka, Meduza i druge, u antičkim su književnim tekstovima moćne žene koje raspolažu silama nedohvatljivima "običnim" ljudima i nisu uvijek zle i zastrašujuće, sklone uništavanju. ${ }^{1}$ Štoviše, njihov je maleficij često tek reakcija, osveta za učinjenu im nepravdu ili nanesenu povredu, kada se

\footnotetext{
${ }^{1}$ Tako, na primjer, o Hekatinim zlodjelima u antičkoj književnosti nema ni riječi (doduše, nema mnogo ni sačuvanih tekstova u kojima se uopće spominje, tek u Hesiodovoj Teogoniji i kod Pauzanije), dapače, ona je i zaštitnica i pokroviteljica bogatstva i plodnosti te su žrtvenici i oltari posvećeni njoj bili često
} 
ni ne koriste nužno svojim moćima, poput tragične Medeje ili jezive Lamije, ${ }^{2}$ ako o njemu uopće ima spomena u mitu ili pak tragediji. Usporedno s likom moćne žene-čarobnice, često božanskoga podrijetla ili na razmeđu bogova i ljudi (što uostalom i jest Platonova definicija demonskoga), u antičkoj se književnosti javljaju i likovi vještica koje nemaju osobitih moći, tek umijeće spravljanja čarobnih napitaka i poznavanje ljubavne magije, poput Fotide i Pamfile, dobronamjernih ali nespretnih vještica iz Apulejeva Zlatnoga magarca, na koje se obilato naslanjaju likovi iz srednjovjekovne i renesansne ${ }^{3}$ književnosti i koji nerijetko imaju potencijal za komično. Premda je u okviru ovoga teksta nemoguće obuhvatiti sve nijanse lika vještice od antike do ranoga novoga vijeka (a niti mu je to nakana), moguće je, ipak, ponuditi ponešto uopćenu sliku o uvjetno dvama prevladavajućim tipovima književnih vještica: moćnima, s nadnaravnim sposobnostima te komičnima, nespretnima u čaranju. Dakle, književnost do ranoga novog vijeka gotovo uopće ne poznaje konstrukciju vještica kakve su nam znane iz pravnih dokumenata i zapisnika sa suđenja u doba masovnih progona, a od kraja 15. stoljeća i iz vizualnih umjetnosti, ponajprije slikarstva. ${ }^{4}$ Dakako, književni se likovi unutarnjom logikom teksta i umjetničkoga stvaralaštva, koje ne mora "opisivati” ili reflektirati zbilju, razlikuju od lika vještice/vješca iz pravnih dokumenata, a

dijelom atenskih domova, a o njima su brigu vodile isključivo žene (vidi Slapšak 2013: 88-92), predane održavanju tradicionalno "ženske domene" - doma, obitelji, vrta, usjeva, domaćih životinja itd.

${ }^{2}$ Lamija, polužena i poluzmija, koja je u nekim varijantama mita bila Hekatinom, a u nekima Posejdonovom kćeri, postala je čudovištem koje proždire djecu (vlastitu i tuđu) Herinom odmazdom za to što je bila Zeusovom ljubavnicom (Horacije, Ars poetica), a kasnije se pojavljuje i u folkloru mnogih zemalja kao lik iz predaja mnogočime nalik vampirima i sukubima, a može se naći i poveznica s Babom Jagom. U kasnom srednjovjekovlju i tijekom ranoga novoga vijeka u demonološkim traktatima lamija postaje sinonimom za vještice (npr. kod Johana Wiera u De prestigiis daemonum et inacantionibus ac venificiis iz 1563., ali i drugdje). Iz toga je jasno vidljiva poveznica između infanticida i vještica, tako česta u optužnicama, priznanjima osuđenih za vještičarstvo, ali i u predajama, pričama i bajkama.

${ }^{3} \mathrm{U}$ književnosti renesanse, a posebno u engleskoj, dolazi do rodne stratifikacije uporabe magije odnosno čarobnjaštva u kreiranju likova: čarobnjak nije proskribiran kao zao, nego kao moćan čovjek koji je repozitorij znanja o prošlosti i budućnosti određene nacije te je ovladao prirodnim silama (najilustrativniji je primjer Shakespeareovog Prospera), dok se žensko bavljenje magijom proskribira kao negativno i opasno (vidi više u Purkiss 1997: 179-199).

${ }^{4}$ Naime, u slikarstvu potkraj 15. stoljeća i početkom 16., ponajprije na crtežima, grafikama i drvorezima autora iz južne Njemačke poput Hansa Baldunga Giena, Albrechta Altdorfera, Albrechta Dürera i dr., a kasnije i iz flamanske i nizozemske škole poput Lucasa Cranacha, Pietera Brueghela, Hieronymusa Boscha i dr., nastaje radikalno nova ikonografija vještičarstva, dotad posve neuobičajena i za književnost i za vizualne umjetnosti. Tako je vještičarstvo prvi put prikazano kao isključivo ženski grijeh na drvorezima Hansa Baldunga, objavljenim u više od dvadeset izdanja jednoga od najutjecajnijih demonoloških traktata, De lamiis et phitonicis mulieribus (1489.) Ulricha Molitora, koji su potom doživjeli bezbroj kopija i varijacija. Na tim se drvorezima, između ostaloga, prvi put pojavljuje i prikaz vještičjega kotla, kasnije osnovnog dijela stereotipnoga kôda vještičarstva podjednako u vizualnim umjetnostima kao i u (usmenoj i pisanoj) književnosti. Više o tome u npr. Davidson (1987); Sullivan (2000); Zika (2002) i dr. Osim toga, Dürerove grafike uspostavljaju dvojni vizualni stereotip vještica: ili su mlade, putene i zavodljive poput onih prikazanih na grafici Četiri vještice iz 1497., ili su stare, oronule i ružne poput one koja jaše na jarcu prikazane na slici iz 1500., a koji potom ulazi i cirkulira podjednako u usmenoj kao i pisanoj književnosti. 
posebno od onih iz zapisnika sa suđenja za vještičarstvo, premda se na njih ponekad oslanjaju.

No dok vještice iz umjetnosti ipak jesu fikcijski, imaginarni likovi, one iz zakonodavnih akata diljem Europe čini se da ipak - nisu. Naime, zajedničko, dijeljeno vjerovanje u realitet vještica i njihovo zlo-činjenje odražava se ne samo u mitovima, pisanoj i usmenoj književnosti, nego i u mnoštvu zakonskih odredbi i podzakonskih akata još od antike pa sve do kasnoga 18. stoljeća u većem dijelu Europe. ${ }^{5}$ Premda je magija još u doba staroga Rima bila dijelom i svakodnevna života i bogoslužja (tzv. divinatio), neki oblici čarobnjaštva odnosno vještičarenja i tada su se strogo kažnjavali, poput maleficija ili pak korištenja magije za osobni (nedopušteni) probitak (usp. Ankarloo i Clark 1999, 2001). ${ }^{6}$

Vjerovanje u nadnaravne sile i vještice te prakticiranje magije nisu, naravno, nestali s pojavom kršćanstva, nego su nastavili supostojati s njime. Prema tim "reziduama" poganskoga svjetovna i crkvena vlast zauzele su drukčija stajališta sve do ranoga novog vijeka. Oslanjajući se na rimsko pravo i zapravo ga umnogome izravno kopirajući, tijekom srednjovjekovlja te ranoga novog vijeka nastaju zakonske odredbe o čarobnjaštvu diljem Europe, no one su bile važne i važeće samo na sekularnim sudovima, dok se crkveno pravo u definiranju vještičjega zločina i vještičarstva oslanjalo ponajprije na teološke rasprave i demonološke traktate.

Premda je Crkva od početaka kršćanstva osuđivala svako prakticiranje magije kao herezu i apostaziju, do formiranja inkvizicije u 12. stoljeću vidljiva je iz propisa o vještičarstvu i stanovita distanca ili čak skepsa prema određenim aspektima vjerovanja u vještice poput noćnoga leta ili utjecaja na atmosferske prilike kako bi se izazvale vremenske nepogode te pretvaranja jednog bića u drugo, najčešće čovjeka u neku životinju (usp. Bayer 1982: 61-6; Maxwell-Stuart 2001: 1-25), što je sve kasnije činilo kumulativnu koncepciju vještičarstva koja zadobiva jasne konture potkraj 14. stoljeća.

Upravo su demonološki traktati, premreženi vjerovanjima i predajama, imali iznimno važnu ulogu u konstruiranju prijetećeg, monstruoznog lika

\footnotetext{
${ }^{5} \mathrm{U}$ okviru ovoga rada nemoguće je nabrojati sve pravne akte brojnih europskih zemalja ili pokrajina kojima se sankcioniralo vještičarstvo, odnosno maleficij te stoga upućujem na neke autore koji su dali podrobne popise i/ili analize: npr. Bayer (1982: 26-129); Levack (2004); Levack (2006).

${ }^{6}$ Jedan od važnijih izvora za rekonstrukciju antičkoga poimanja čarobnjaštva je i Apulejeva Apologija: govor u vlastitu obranu, o magiji, tekst koji je na razmeđu književnosti, magije i demonologije, a iz kojega doznajemo da je Apulej bio osumnjičen da se koristio magijom kako bi stekao naklonost žene i domogao se njezina novca. Iz toga slučaja, a uostalom i iz cjelokupnoga rimskoga prava, jasno je da se nije kažnjavao samo maleficij, nego i uporaba magije za vlastiti boljitak a protiv dobrobiti drugih. Apulej je zahvaljujući tome suđenju, ali ponajprije zahvaljujući svojim prirodoznanstvenim spisima, romanu Metamorfoze te tekstovima o magiji još stoljećima kasnije uživao ugled najvećega poganskoga čarobnjaka, kojeg spominju i ozbiljni crkveni oci poput Laktancija i svetog Augustina (usp. Novaković 1991: 75-89). Tako se od antike oblikuje lik ozbiljnoga, eruditskoga, maskulinog čarobnjaka-znanstvenika u opreci s nespretnom, opasnom ili naprosto neukom vješticom.
} 
vještice (ponajprije žene kao vještice) koji je bio metom progona tijekom ranoga novog vijeka - o njihovom utjecaju na diseminaciju tako ocrtane opasnosti od vještica dovoljno je pripomenuti kako je samo Malleus maleficarum bio tiskan trinaest puta između 1486. (kada je prvi puta objavljen) i 1520., dakle na samim počecima masovnoga lova, kada i sekularno zakonodavstvo prihvaća teološku definiciju zločina te pokreće procese protiv osumnjičenih u sljedećih gotovo 300 godina diljem Europe.

Već spomenuta kumulativna koncepcija vještičarstva uključivala je, između ostaloga, infanticid, antropofagiju, orgijastična okupljanja, perverzne gozbe, noćne letove na sabat te ugovor s đavlom, dakle redom već poznate elemente iz prijašnjih optužbi protiv raznih heretičkih skupina poput valdenza i katara, ali i iz optužbi protiv drugih Drugih ${ }^{7}$ poput židova, muslimana, Turaka i dr. (usp. Cohn 1993: 51-53, 73-6; 77-8; Bayer 1982: 117-21; Ankarloo i Clark 1999; Maxwell-Stuart 2001: 17-23; Kieckhefer 2008: 23-30), no koji do progona vještica nikada prije nisu bili svi pripisivani samo jednoj skupini, u ovome slučaju ponajprije ženskoj skupini. Iako su podaci o broju osoba spaljenih zbog vještičarstva često bili poligonom za političke i ideološke obračune (pa se tako 70-ih i 80-ih godina prošloga stoljeća manipulira s fiktivnim podatkom od čak 9 milijuna spaljenih žena), ${ }^{8}$ višedesetljetnim istraživanjima po arhivima europskih gradova došlo se do procjene da je stvaran broj žrtava između 60 i 90 tisuća, od čega su tri četvrtine bile žene (Behringer 1997; Voltmer 2006: 1210). Dakle, tijekom ranoga novog vijeka događa se značajna promjena u percepciji i konstrukciji vještica - one se iz relativno marginalne pojave transformiraju u radikalno zle i opasne podjednako za Crkvu, državu i pojedince.

${ }^{7}$ U tekstu ću se koristiti pojmom Drugoga oslanjajući se na Lacanovu koncepciju strukture subjektiviteta, pod čime se razumije da je Drugi dijelom simboličkoga registra i u čijem pogledu subjekt zadobiva/ gradi vlastiti identitet, dok je drugi dijelom imaginarnoga i, prema Lacanu, "nusproizvod" formiranja ega u stadiju zrcala. Lacan u svojoj teoriji subjektiviteta izmješta ego u područje imaginarnog te subjektu pripaja upravo nesvjesno kao primarno obilježje, odnosno njegov subjekt tako postaje subjekt nesvjesnog. Svijest odnosno samosvijest subjekta je za Lacana tek zabluda, iluzija ega. Strukturiranje ega počiva na nerazaznavanju "originala" od kopije u stadiju zrcala, odnosno na poistovjećenju sa zrcalnim odrazom, čime se subjekt alijenira od samoga sebe i počinje razvijati narcističko vezivanje, ali i agresivne impulse koji su ponajprije usmjereni na subjektova najvećeg rivala - samoga sebe. Taj odraz ili projekciju ega Lacan naziva malim drugim i označava kao a (prema francuskom autre), koji je "drugi koji uopće nije drugi, jer je u svojoj biti udružen s egom u odnosu koji je uvijek zrcalan, izmjenjiv" (1978). U II. seminaru pojmu malog drugog Lacan pridružuje, ili prije suprotstavlja, pojam velikog Drugog, A (Autre). Taj Drugi je drugi subjekt, ali je prvenstveno područje simboličkoga, tj. jezika i nesvjesnoga, poredak "u kojem subjekt kao različit od ega dolazi u postojanje, i to na takav način da je uvijek rascijepljen i isprekidan" (Bowie 1991: 92), odnosno za Lacana nesvjesno je diskurs Drugog (Lacan 1966: 16).

${ }^{8} \mathrm{U}$ počecima feminističkoga pokreta, u kojem je vještica imala emblematsku, programatsku ulogu, različite autorice spekulirale su o 3, 6 ili čak 10 milijuna pogubljenih žena u doba najvećih progona (usp. Barstow 1988: 7), a npr. Andrea Dworkin u knjizi Woman-Hating iz 1974. iznosi podatak o 9 milijuna spaljenih žena. Takav je pristup, u mnogim segmentima neutemeljen i mitotvoran, ipak uspio prvi put upozoriti na očitu, ali dotad posve nevidljivu činjenicu u historiografiji: da je povijest progona vještica zapravo ponajprije povijest žena. 
Iz ovako kratkoga presjeka mnogostrukih konstrukcija vještice u književnome, pravnome i teološkom diskursu razvidno je da vještice i vještičarstvo nisu fiksni/fiksirani pojmovi, nego pak osobito nestabilni i polisemantički - njihovo je značenje stalno mjesto sukoba i pregovora između različitih individualnih autora, skupina pa i kultura, pogotovo tradicijske i učene; mjesto u kojem se prelamaju često suprotstavljene definicije, ideje i vjerovanja koji su kulminirali strahom i panikom te nesmiljenim progonima.

Takva množina odredbi i mijena kroz povijest potaknula je i kasnije brojne interpretacije: za ljude ranoga novoga vijeka vještice su bile realnost, u 19. stoljeću prevladalo je mišljenje da su one individualna i kolektivna fantazija, dok su stavovi znanstvenika u 20. i 21. stoljeću podijeljeni te često meandriraju između (hiper)racionalizacije pojedinih motiva iz optužbi i psihopatologizacije cijeloga razdoblja ili "tek" pojedinih skupina, najčešće samih vještica ili pak svećenstva.

O razlozima i povodima progona vještica, izvorima njihova konstruiranja, podrijetlu motiva iz optužnica i priznanja do danas je napisano nepregledno mnogo studija, ${ }^{9}$ no začuđujuće malo autora ${ }^{10}$ je uopće uzelo u obzir zapisnike sa suđenja kao osobne, individualne "upise" vjerovanja, fantazija ${ }^{11}$ ili projekcija u teološki i pravno konstruirane vještice. Dakako, vještice su važna društveno i politički, pa i ideološki upotrijebljena Drugost koja je poslužila u kanaliziranju tjeskoba, sukoba i agresije te u (ponovnom) uspostavljanju reda i društvenih normi, čemu u prilog govori i činjenica da je progona vještica tek rijetko bilo u vrijeme ratova ili ozbiljnijih političkih kriza, no smatram da je izvorišta vještičjega imaginarija moguće potražiti i u individualnoj strukturi subjektiviteta ljudi ranoga novoga vijeka, u kojoj se uvijek zrcali i kolektivna Drugost.

\footnotetext{
${ }^{9}$ Geoffrey R. Quaife u knjizi Godly Zeal and Furious Rage (1987) navodi čak četrdesetak teza različitih autora o razlozima masovnih progona koje i danas uglavnom cirkuliraju u literaturi, počevši od utjecaja reformacije i protureformacije, utjecaja inkvizicije, korištenja torture kao glavne metode u dobivanju priznanja, pretjeranog vjerskog zanosa svećenstva; potisnute seksualnosti svećenika; ratova između religija, stvaranja modernih država do razvoja medicine; razvoja kapitalizma; pokušaja zatiranja poganskih kultova; upotrebe droge; siromaštva izazvanoga velikim klimatskim promjenama, do društvenih i kulturalnih sukoba ili pak rastuće mizoginije. No kako su progoni vještica kompleksan fenomen dugoga trajanja, ni jedna od navedenih teza nije se pokazala uvjerljivom ili dostatnom u cjelini, a još manje provjerljivom na mikrohistorijskom nivou.

${ }^{10}$ Ovdje svakako valja spomenuti Lyndal Roper, povjesničarku koja je u knjizi Oedipus and the Devil (1994) uspjela pokazati kako historiografija i te kako "trpi” feministički i klajnovski psihoanalitički kategorijalni aparat te Diane Purkiss čija je studija The Witch in History iz 1997. ukazala na plodotvornost čitanja zapisnika kao osobnih narativa o vlastitome životu, strahovima i fantazijama osuđenih žena, u kojima se pregovarački dolazi do dijeljene konstrukcije vještica.

${ }^{11}$ Pod fantazijom zapravo podrazumijevam psihoanalitičko, Lacanovo koncipiranje fantazme koja nije svedena na imaginaciju odnosno maštu, nego je naglašena njezina protektivna uloga, vrsta obrambenoga mehanizma - kao zaštita od manjka u Drugome, koja je u svojem temelju nesvjesna (usp. Evans 1996: 59-61).
} 
Smatram kako je iz zapisnika sa suđenja moguće iščitati vjerovanja te osobne konstrukcije vještice kroz strahove i projekcije onih koji u procesima sudjeluju - od tužitelja do osumnjičenih te na koncu i optuženih, a koji su bili iskazani, ispripovijedani nametnutim, a potom i introjiciranim, demonološkim rječnikom. Kako je zamijetila i Lyndal Roper (1994), procesi ispitivanja i uobličavanja u priču o vlastitome životu u neku su ruku nalik na proces psihoanalize, u kojem se između optužene žene i njezina ispitivača razvija odnos u kojem prevladavaju transferi i kontratransferi te se tako $u$ priču uzglobljuju i dijelovi kolektivnoga nesvjesnog. U interpretaciji takvih tekstova koji govore o vjerovanjima i fantazijama lacanovska psihoanaliza gotovo da se sama nameće kao analitički okvir iz nekoliko razloga: prvo, zbog prominentne pozicije koju pojam Drugoga ima u Lacanovoj teoriji, a drugo, zbog historiziranosti njegovih psihoanalitičkih procedura, što pak omogućuje uporabu psihoanalitičke kritike za razdoblja i fenomene i prije njezina uspostavljanja. ${ }^{12}$

Takvom se analizom, odnosno interpretacijom ne nastoji ponuditi novi "veliki povijesni narativ" kojim bi se pojasnilo razloge progona vještica u određenom trenutku, a kamoli u njihovoj geografskoj i vremenskoj protežnosti: razmatranje progona koji su trajali i više od tri stotine godina kao uvijek iste "epizode" europske povijesti pokazalo se dosad u konačnici pogrešnim. ${ }^{13}$ Umjesto toga, zanimali su me zapisnici kao priče o individualnome i kao priče individualnih subjekata koji jezikom ili kroz jezik vještičjega imaginarija reflektiraju i kolektivno nesvjesno.

Što se tiče hrvatskih masovnih progona i zapisnika sa suđenja, oni su nedvojbeno dio ženske povijesti i to ponajprije grada Zagreba i sjeverozapadne Hrvatske krajem 17. pa sve do sredine 18. stoljeća, o čemu svjedoči i broj optuženih žena koji je iznosio gotovo $95 \%{ }^{14}$ Time se Hrvatska uvrštava na

${ }^{12}$ Dok kod Freuda nije bilo govora o subjektu kao dijelu teorije o psihičkom aparatu nego je naglasak stavljen ponajprije na ego, Lacan prvi uvodi pojam subjekta te upozorava na ključnu razliku između ega i subjekta, koji pripadaju posve različitim psihičkim registrima: subjekt simboličkom, a ego imaginarnom. On smješta formiranje modernoga ja ili ega upravo u doba ranoga novog vijeka, točnije u polovinu šesnaestog i početak sedamnaestog stoljeća (Lacan 1978: 16), a formiranje modernog (psihoanalitičkog) subjekta locira u kartezijanskom subjektu, čime omogućuje uspostavljanje povijesno postojećeg predanalitičkog subjekta (usp. Matijašević 2006: 160).

${ }^{13}$ Richard Kieckhefer ustanovio je da se razdoblje progona vještica može razdijeliti u najmanje tri segmenta različito motiviranih optužbi: u prvom razdoblju, između 1300. i 1330., suđenja su bila ponajprije politički motivirana jer je većina vještica bila optužena za upotrebu magije protiv političkih protivnika, $\mathrm{tj}$. vladajućih. U sljedećem razdoblju, od 1330. do 1375., suđenja više nemaju politički karakter nego su, pak, usmjerena na vještičarenje kao maleficium. U posljednjem razdoblju prije početka masovnih suđenja, od 1375. do 1420., sve se više javljaju optužbe vezane uz dijabolizam, odnosno ugovor s vragom, prvo u Italiji a potom i drugdje, koji kasnije postaje okosnicom svih procesa (Kieckhefer 1976: 10-26).

${ }^{14} \mathrm{U}$ ovome radu analizirala sam zapisnike sa suđenja isključivo iz razdoblja masovnih progona vještica u sjeverozapadnoj Hrvatskoj, dakle od 1698. do 1758. kada se u potpunosti prihvaća teološka definicija zločina, koristeći se ponajprije onima koje je prikupio i objavio Vladimir Bayer u knjizi Ugovor $s$ đavlom (1952/ treće izdanje iz 1983). Odabir sjeverozapadne Hrvatske (koja je bila u sastavu Habsburške Monarhije), odnosno ponajprije zagrebačkih suđenja bio je i jedini moguć: naime, za ostatak Hrvatske koji je 
sam vrh europskih progona žena-vještica, jer se u većini europskih zemalja taj omjer kretao oko dvije trećine žena naspram jedne trećine muškaraca optuženih za vještičarstvo. Dakle, u kontinentalnoj Hrvatskoj se krajem 17. stoljeća događa znatna izmjena u percepciji i konstrukciji žena kao vještica, kada one postaju glavnom prijetnjom, rušilačkom snagom kojoj se valjalo suprotstaviti: donekle paradoksalno, tek s progonima vještica žene u Hrvatskoj postaju vidljive sudionice gradskoga života i konačno se upisuju u mušku povijest ranoga novog vijeka. Zapisnici sa suđenja vješticama govore mnogo o vidljivome, svakodnevnom životu na Gradecu onoga doba, ali i o onome nevidljivom, nesvjesnom dijelu svijeta njegovih stanovnika koje je imalo važnu ulogu u kreiranju slike monstruoznih žena. Dakako, legitimno je propitati status takvih zapisa kao osobnih, ženskih narativa jer su svi zapisnici zabilježeni muškom rukom i to u trećem licu singulara, uglavnom nakon dugotrajne torture i ispitivanja, a uz to - pisani su dvama jezicima: uvodni, službeni dio dokumenta pisan je latinskim, a optužba ili priznanje starijim kajkavskim idiomom. Kako napominje i Purkiss (1997: 91-92), u ranome novom vijeku teško je govoriti o "autentičnim" ženskim tekstovima ili iskazima jer su gotovo uvijek uključivali i muške intervencije ili upisivanja. No iako su ženski iskazi na sudu bili dijelom diskursa o vješticama koji je dolazio iz "visoke" i to pretežito maskuline kulture, proglasiti ih tek pamfletima, a žene tek "glasnogovornicama" patrijarhalnoga sustava i dominantne ideologije činilo mi se ipak i reduktivnim i netočnim: takvim se postupcima, karakterističnim za historiografiju, ali i za mnoge rane feminističke interpretacije, ženama ranoga novog vijeka ponovno dokida pravo glasa i odriče njihov udio u sukreiranju i pregovaranju "sebe kao vještice". Iskazi optuženica sadrže i svojevrsni višak koji nije uvijek razumljiv isključivo iz očišta teoloških, pa onda i patrijarhalnih predodžbi o ženama kao vješticama. Ili, kako kaže Lyndal Roper, "one nisu bile samo projekcije muških fantazija o zlu nego njegova aktivna utjelovljenja" (Roper 1994: 20).

S obzirom na vještičji imaginarij koji je uključivao let na metli ili nekoj životinji (najčešće psu ili jarcu), seksualni odnos s vragom, orgije na sabatu, ugovor s đavlom te obilježenost tijela đavoljim pečatom i dr., očekivala sam da ću u sudskim iskazima pronaći kulminaciju seksualnoga antagonizma između muškaraca i žena. No, pomno čitanje i analiza iskaza sa suđenja, ali i drugih pravnih dokumenata ukazali su da im zajednička neuralgična točka nije anksioznost vezana uz seksualnost, nego pak "problematičan" odnos

bio pod vlašću ili Osmanskoga Carstva ili Mletačke Republike uglavnom nemamo sačuvane zapisnike sa suđenja, a niti podatke da je masovnih progona uopće bilo u navedenom razdoblju. Razdoblje od 13. stoljeća, otkad datiraju prvi sačuvani statuti kojima se sankcionira prakticiranje magije, odnosno maleficij, a koji dolaze iz Dalmacije, Istre i Primorja, nije uključeno u ovo istraživanje, premda je važno napomenuti kako su statuti pisani hrvatskim jezikom (a za razliku od onih na latinskome) bili rodno diskriminatorni s obzirom na moguće prekršitelje. Naime, Vinodolski zakon, Statut otoka Krka, Poljički statut te Statut trsatski apostrofiraju isključivo žene kao moguće vještice, dok muškarce uopće ne spominju. 
prema tijelu i tjelesnosti. ${ }^{15}$ Tijelo se u procesima, jednako kao i pravnim aktima toga doba, može razmatrati u više aspekata: realno/fizičko, izmučeno tijelo, tijelo kao izvor užitka, tijelo Drugoga, imaginarno tijelo, tijelo kao ploha društvenog i kulturnog upisivanja i kao mjesta zrcaljenja, uspostavljanja političke moći - samo su neki od načina kako su se sve manifestirala tijela, odnosno usmjerenost na tijelo. Ona je bila vidljiva u iskazima optuženica, iskazima svjedoka te u sudskim procedurama ispitivanja i, na kraju, u javnim ritualima prikazivanja izmučenih, odznačenih tijela vještica te njihova spaljivanja te je u tijesnoj vezi s problemom Drugosti i psihičkim mehanizmima koji stoje iza takvih odnosa prema tijelima, odnosno koji sudjeluju u njegovu konstituiranju. Uostalom, osnovna manifestacija vještičje Drugosti bila je sadržana u i na tijelu: njihovo je tijelo lakše od ljudskoga, njegovi su dijelovi neosjetljivi na bol ${ }^{16}$ te im je tijelo označeno, obilježeno posebnim pečatom vraga kao vrhunskog označitelja. ${ }^{17}$ Manifestacije tijela u progonima vještica poslužile su za čitanje manifestacija nesvjesnog, no ne i iracionalnog te s njime povezanih predodžbi koje su konstituirale vještičji imaginarij.

\footnotetext{
${ }^{15} \mathrm{Na}$ odnos prema tijelu i tjelesnosti nesumnjivo je velik utjecaj imao i proces protureformacije, koji se intenzivira povratkom isusovaca na Gradec i oformljivanjem kolegija 1606., ali i dolaskom franjevaca, klarisa i benediktinaca. S povratkom brojnih redova u Zagreb početkom 17. stoljeća započinje dugi proces korigiranja ponašanja i vjerovanja stanovništva te njihova discipliniranja, o čemu svjedoče kronike isusovačkoga reda, ali i neki pisci i propovjednici poput Jurja Habdelića iz čijih se djela mogu rekonstruirati razni aspekti svakodnevnoga života. U tom se razdoblju, između ostaloga, mijenjaju predodžbe o tijelu te se kritizira putenost i seksualnost, a posebno ženska, jer bi tijelo trebalo imati tek reproduktivnu svrhu: žensko pokazivanje tijela kao i užitak proskribiraju se kao osobito grješni, a sve se više nameće predodžba Djevice Marije kao idealne žene i majke. Takvi procesi zasigurno nisu mogli proći bez tjeskoba, frustracija i otpora, o čemu također piše i sam Habdelić u Pervi otcza našega Adama greh (1674.), moralno-didaktičnom djelu kojim se nastojala potaknuti duhovna, ali i tjelesna reforma građana. No, u okviru ovoga rada nemoguće je razmotriti brojne implikacije koje je imala protureformacija na discipliniranje tijela, koje se tek jednim dijelom mogu iščitati i iz zapisnika sa suđenja vješticama.

${ }^{16}$ Obje predodžbe o vještičjem tijelu svoje izvorište imaju u inkvizicijskom priručniku dominikanca Kramera, Malleus maleficarum, na osnovi kojega se kasnije razvija niz sudskih procedura usmjerenih na pretraživanje i pregledavanje tijela osumnjičenih.

${ }^{17}$ Jedna od temeljnih odrednica vještičarstva bio je dijabolizam koji je podrazumijevao ugovor s đavlom, koji je mogao biti ili u pisanome obliku ili u obliku pečata na tijelu. No kako je znatan dio ranonovovjekovnoga stanovništva bio nepismen (u Hrvatskoj su pretežno bile optužene neobrazovane žene iz redova obrtnika ili seljaka), pisanoga ugovora između đavla i njegove sljedbenice nije ni moglo biti te se stoga temeljito pregledavalo žensko tijelo u potrazi za tragom đavoljeg Drugog. Takvo je vjerovanje o označenosti tijela neobično nalik Lacanovoj postavci o tome da se tijelo osvaja, zadobiva uz pomoć Drugoga koji ga zrcaleći vraća subjektu, odnosno da je tijelo subjekta upisna ploha Drugoga. Vrag je prema tome onaj Drugi koji subjektu/vještici pomaže pri ulasku u registar simboličkoga - jezika, društva, kulture, samo što je u ovome slučaju taj svijet simboličkoga nešto drukčiji. Uloga vraga koji se upisuje i označuje tijelo te ga uvodi u društvo jest inače uloga oca u procesu edipacije. Svijet simboličkoga koji nastanjuju vrag kao strašni otac i vještice kao proždiruće (anti)majke te demoni koji nemaju tijela, nego zaposjedaju ljudska čini se kao izokrenuti "normalni” svijet, kao svijet noćnih mora, utjelovljenje najdubljih strahova, odraz nesvjesnoga. Vrag i vještica tako postaju antipodi roditelja, pri čemu je vještičja žudnja usmjerena $\mathrm{k}$ đavlu. Vrag je taj koji preispisuje njezino tijelo i smješta užitak u određene zone - na mjesto pečata. Stoga je bilo važno detaljno pretražiti tijelo i ukloniti trag Drugoga, odnosno ukloniti označitelja. Tek odznačeno tijelo može zauzeti drugu poziciju u društvu i eventualno se vratiti "na pravu stranu", u normalan društveni poredak nakon što prizna vlastite grijehe i pokaje se.
} 
Upravo nam ti iskazi mogu poslužiti za iščitavanje konstrukcije subjekta i manifestacija nesvjesnog u njegovu historijskom kontinuitetu, odnosno za propitivanje što je historijsko u subjektivitetu.

Premda zapisnici iz 1699. godine, kada u kontinentalnoj Hrvatskoj počinju masovni procesi, nisu osobito opsežni i detaljni, a postaju detaljniji u 18. stoljeću, ipak je moguće izdvojiti dva osnovna motiva povezana s tijelom koji se provlače kroz većinu i optužbi i priznanja, a to su infanticid i antropofagija, dok je treći, ništa manje važan, povezan s prostorom doma i hrane.

Narativi ili fragmenti narativa kojima dominiraju slike raskomadanih tijela, ubijene djece od koje se spravljala vještičja mast, ubijenih životinja ili uništenih usjeva, gozbi na kojima se jede hrana koja izaziva gađenje ili kojom se krše tabui - sve su to na određeni način dijelovi tradicionalno ženske domene, dakle rađanja ili uništenja života, skrbi o domu ili njegovoga razaranje, prirode... Pozicija žene jest ona na razmeđu prirode i kulture, imaginarnoga i simboličkoga te je ona ta koja ima moć koja zastrašuje jer je sveobuhvatna i subjekt joj teško može izmaći. Ženu kao majku i kao vješticu valja svladati kako bi subjekt mogao dospjeti u prostor simboličkoga, u jezik i društvo.

Psihoanalitička kritika doista ne bi bila prvi izbor u razmatranju odnosa prema tijelu i tjelesnosti da Lacan nije posvetio znatnu pozornost tijelu preko njegove povezanosti s psihičkim registrima, ponajprije s imaginarnim i simboličkim. Za interpretaciju iskaza, pa onda i određenih dijelova vještičjega imaginarija ključan je stadij zrcala ${ }^{18}$ kao središnje mjesto formiranja ega, ali

${ }^{18}$ Stadij zrcala možda je najproblematičniji dio Lacanove teorije i doživio je brojne kritike. I Lacanu i samoj koncepciji zrcalne slike zamjeralo se štošta: od toga da nije ni spomenuo svoje prethodnike na čiji se rad oslanjao (usp. Roudinesco 2003: 27-30; Borch- Jacobsen 1991: 46; 248-249), do toga da je strukturiranje ega suviše usmjerio isključivo na vizualni aspekt (npr. Tallis 1988: 153), pa i toga da se postavlja pitanje tko prepoznaje sliku ako ne postoji ništa prije same identifikacije (Borch-Jacobsen 1991: 66), da navedem samo neke sporne aspekte Lacanove teorije o nastanku ega. Pa ipak, koliko god se pojedini dijelovi Lacanova stadija zrcala činili upitnima - posebno identifikacije s drugim putem slike, odnosno njezino pounutarnjivanje - novija neurobiološka istraživanja (dakle, "prava" znanstvena istraživanja) pokazala su da se subjekt od trenutka rođenja konstruira na temelju informacija koje se prenose zrcalnim neuronima, podjednako u odnosu na druge kao i na samoga sebe. Marco Iacoboni, neuroznanstvenik sa Sveučilišta UCLA, sa skupinom kolega nastavio je istraživanja zrcalnih neurona u mozgu koje su otkrili parmski znanstvenici, a koje je temeljito izmijenilo dosadašnje spoznaje o mozgu i psihi. Bilo bi suvišno sada izlagati cijeli tijek istraživanja na pojedinim dijelovima korteksa koje su izučavali, no implikacije takvoga proučavanja su iznimno zanimljive i upućuju na zrcaljenje, odnosno oponašanje (u kojem i slika i zvuk imaju veliku ulogu) kao ključno za formiranje individue, ali i društava, običaja, ponašanja, vjerovanja i dr. Premda se, dakako, nisu bavili formiranjem subjekta ili njegova ega, u nekom se trenutku pokazala važnom paralela s filozofijom fenomenološke tradicije, a posebno s pojmom intersubjektiviteta. Iacoboni tako kaže: "[Z]apadnom kulturom dominira individualistički, solipsistički okvir unutar kojeg se zdravo za gotovo uzima postavka o potpunoj razdvojenosti ja od onog drugoga. [...] Unatoč takvom prevladavajućem gledištu, zrcalni neuroni ponovo sjedinjuju ja upravo s onim drugim. Djelovanje tih neurona podsjeća nas na izvorni intersubjektivitet, koji se, naravno, svodi na početne interaktivne sposobnosti što se očituju i razvijaju kroz odnose i doticaje majka-dijete, odnosno otac-dijete. Jesu li zrcalni neuroni nastali i oblikuju li se ovim izvornim intersubjektivitetom? Vjerujem da je to točno. Premda vjerojatno neki zrcalni neuroni počinju djelovati već rano i olakšavaju djetetove najranije interakcije, vjerujem kako najveći dio našeg sustava zrcalnih neurona, zapravo, kroz takve interakcije nastaje mjesecima i godinama" (Iacoboni 2012: 133). 
koji je važan i za sve drugostupanjske identifikacije. Iako je Lacan upotrijebio riječ stadij, zapravo je riječ, kako naglašava Roudinesco, o psihičkoj ili ontološkoj operaciji, a ne prolaznoj fazi djetetova/subjektova razvoja (Roudinesco 2003: 29). Upravo zbog "preranoga rođenja", dok dijete još nije ovladalo motoričkim sustavom, a svoje tijelo doživljava tek fragmentarno, dolazi do pogrešnoga prepoznavanja vlastitoga odraza/slike kao sebe samoga, dok vlastito tijelo doživljava kao nešto strano i zastrašujuće, kao rivala. Tada se ego strukturira na temelju predodžbi koje generiraju drugi (Elliot 2012: 65) i traži potvrdu od Drugoga kako bi održao privid cjelovitosti, što je već naznaka iskoraka prema simboličkome. Lacanovo viđenje tijela je specifično:

[S]tadijum ogledala je drama čiji se unutarnji napon baca od nedostatnosti ka predujmljivanju [anticipiranju] - i koja subjektu, uhvaćenom na mamac prostornog poistovećivanja, snuje fantazme koji nadolaze jedan za drugim od iskomadane slike tela, do oblika koji ćemo, zbog njegove potpunosti, zvati ortopedskim - i baca se ka na kraju prihvaćenom oklopu otuđujućeg identiteta, koji će svojom krutom strukturom obeležiti sav mentalni razvoj jedinke. [...] To iskomadano telo [...] redovno se pokazuje u snovima, kada tok analize na izvesnom nivou dosegne agresivno rastvaranje jedinke. Ono se tad javlja u obliku rastavljenih udova i onih organa predočenih u egzoskopiji, koji se krilate i oružaju za unutarnje progone, što je, u njihovom usponu u petnaestom veku ka uobraziljskom zenitu modernog čoveka, zauvek fiksirao u slikarstvu vizionar Jeronim Boš. (Lacan 1983: 9-10, istakla N. P.)

Predodžba o gnijezdu na stablu prepunome penisa koju je opisao Kramer u Malleus maleficarum priziva ovakvu lacanovsko-boschevsku sliku tijela, baš kao i pečati izrezani iz kože te dijelovi tijela podvrgnuti torturi, ali i opisi raskomadanih tijela u iskazima sa suđenja. Prema Lacanu, subjekt ima pristup vlastitom tijelu jedino preko Drugoga koji mu ovjerava njegovu cjelovitost (taj Drugi je uvijek prvo majka), zauvijek se okrećući prema Drugome i neprestano tražeći potvrdu vlastitoga postojanja izvan sebe, u izvanjskome svijetu. Paul Verhaeghe smatra da stadij zrcala ima tri posljedice za svaki subjekt: ${ }^{19}$

Prvo, "ego u nastajanju" stječe kontrolu nad tijelom no to svladavanje podrazumijeva realno/pravo svladavanje koje se nikada neće dogoditi. Drugo, i ego i slika tijela izvorište imaju u izvanjskome svijetu, to jest konstruirani

\footnotetext{
${ }^{19}$ Mnogi su Lacanu zamjerali da je u njegovim izučavanjima formiranja subjektiviteta prilično teško odrediti što bi to bio "zdrav" ili "normalan" subjekt - naime, on smatra da su svi subjekti potencijalno psihotični, a u toj "normalnosti” sudjeluju i neuroze, perverzije i dr. (Chiesa 2007: 7), što dakako ne znači da ne postoji zasebna simptomatologija svakoga od tih poremećaja. Dalo bi se naslutiti da za Lacana nešto poput "normalnoga" subjekta zapravo ne postoji, odnosno normalni su oni koji su prošli kroz sva tri vremena Edipova kompleksa i kod kojih postoji veza između realnoga, imaginarnog i simboličkog. Normalan subjekt tako prema Lacanu ima neke značajke neuroze, perverzije pa i psihoze.
} 
su u procesu otuđenja. Treće, dualno-narcističke karakteristike ovoga stadija stvaraju destruktivnu agresiju (ili ja ili Drugi) unutar dualno-imaginarnoga. (Verhaeghe 2001: 66)

Pritom u stadiju zrcala vlastito tijelo nikada nije vlastito niti postoji pristup njemu kao fizičkome tijelu, ono je uvijek tijelo Drugoga - onoga koje jamči cjelovitost, ali jednako tako i neprestano plaši mogućnošću fragmentacije, pa i rastakanja, nestajanja. Lacan razvija i optički model u prvom seminaru (1953./1954.) i kasnije u tekstu "Remarque sur le rapport de Daniel Lagache" (1966a: 124-163) pomoću kojega prikazuje kako subjekt ima tek ponekad i vrlo malo pristupa vlastitome tijelu - tijelo na taj način postaje ploha za upisivanje simboličkoga, ili označeno tijelo. Kako je majka najčešće taj "prvi Drugi", njezini zahtjevi i žudnje postaju označiteljima djeteta i njegova tijela procesi se događaju s promjenama zahtjeva Drugog (i s promjenama samoga Drugog, što je najčešće otac nakon majke) te tako subjekt zapravo nikada ne posjeduje i ne raspolaže vlastitim tijelom. U tome je smislu prema Lacanu svako tijelo - tijelo histerika.

Kako je Lacan ustvrdio da se u stadiju zrcala nalazi korijen agresivnosti koja je prvo intrasubjektivna, a tek kasnije intersubjektivna (Matijašević 2006: 128), nije nimalo neobično da nakon izlaganja o nastajanju ega slijedi i tekst/izlaganje o agresiji i agresivnosti u njegovim Spisima. U tome tekstu ponovno spominje fragmentirano odnosno raskomadano tijelo u kontekstu kasnijega, naknadnoga prisjećanja toga osjećaja iz stadija zrcala koji se manifestira u "slikama kastracije, demaskulacije, mutilacije, komadanja, iščašenja, vađenja utrobe, proždiranja, rasprskivanja tijela” (Lacan 1966: 104). Takve slike, kaže Lacan, često su u nekom obliku prisutne u dječjim igrama (npr. kidanje glave, ruku ili nogu lutkama, igre rata i sl.), a u slikarstvu ih je najbolje predočio Hieronymus Bosch, kojega spominje i u "Stadiju zrcala".

Znatan dio zapisnika sa suđenja vješticama sadrži slične ili identične slike: predodžbe o raskomadanim tijelima, pojedenim tijelima, ubijenim tijelima sastavni su dio predodžbi o čudovišnim ženama koje prijete subjektu. Svi ti prizori neodoljivo podsjećaju na suvremene filmove strave - imaginarij takvoga žanrovskoga filma ${ }^{20}$ gotovo da je nepromijenjen još od doba progona vještica, čak je ponekad i manje zastrašujući, a posve sigurno je manje razrađen.

${ }^{20}$ Barbara Creed u knjizi The Monstrous-Feminine: Film, Feminism, Psychoanalysis iznosi dominantnu tipologiju ženskih likova u filmovima strave - u većini filmova one su žrtve, a u onima u kojima su glavni likovi dotadašnja čitanja su se koncentrirala na konstruiranje žena kao čudovišnih zato što su kastrirane. Creed obrće takvu "mitsku, patrijarhalnu" interpretaciju i koristeći se postlacanovskom psihoanalitičkom teorijom pokazuje, ponajprije uz pomoć Kristevinog pojma abjekcije (ili zazornosti), da žena u filmovima zastrašuje zato što ima moć stvoriti, kastrirati ili posve poništiti subjekt. Najčešći tipovi ženskih likova su tako majka koja kastrira, vještica, vampirica, monstruozna majka, monstruozna maternica, opsjednuta žena (Creed 1993). 
Opisi vještičjih zlodjela vršenih nad tijelima ili dijelovima tijela - djece, odraslih osoba, životinja - brojni su i jezivi: nerijetko se spominje "čupanje srca”, vađenje utrobe, čak i vađenje krvnih žila i dr. Tako je Jela Škvarić 1699. izjavila na ispitivanju da vještice kada se nađu "jedu čovječje meso" (Bayer 1982: 595); Margareta Dumbović-Boljanec je ispričala "da je Jalžunka, žena Ključarićeva, vještica i da je kuhala i pripravljala dječju glavu, [...] ali kaže da nije jela te dječje glave" (Bayer 1982: 598), dok Kata Dolenc daje detaljnu recepturu za razne bolesti koje vještice mogu nanijeti pa čak i za "povratak iz mrtvih":

Kada vještice uzmu koga, može se izliječiti. Treba potražiti gdje mu je na tijelu krvavo mjesto, pa ga isprati i dati mu da popije, povratit će se, i to brzo. Pa iako (mu) bude pola srca pečeno, mora se povratiti. Ako kada kostima naškode, treba se natrti češnjakom, lukom, bogojavljenskom vodom i izrescima trojega luka, crljenca, kozjaka i opihe veleštine (?), u devet komada da nijedan nema para; moraju (čovjeka) natrag povratiti. Ako mu i dobrano žile uzmu, moraju mu povratiti kad se češnjakovim dračem natare. [...] Isto tako veli, kad putnik ide i namjeri se na vještice gdje se goste pa im stane u zdjelu, a nema kod sebe nikakvih ljekarija, odmah ga pojedu. (Bayer 1982: 600)

Marijana Vugrinec je pak optužena da je Marici Frajt “uzela” desnu ruku i nogu nakon što je odbila pristupiti vještičjoj družbi (Bayer 1982: 683), iako tu nije riječ o doslovnom jedenju dijelova tijela.

Pa ipak, unatoč živim i preciznim opisima kojim su se sve dijelovima tijela vještice gostile, rijetko bi koja od njih priznala da je i sama jela, na primjer, dječju glavu ili pečeno ljudsko srce - o tome se pripovijedalo ili izvještavalo kao o nečemu o čemu su samo čule, nikako ne i sudjelovale. Iz priznanja je vidljiva konstrukcija vještice kao one koja se nalazi na rubnome prostoru, između imaginarnoga/prirode i simboličkoga/društva: njezina je moć povezana s upravljanjem nad prirodom i stvaranjem života, ali i njegovim oduzimanjem - brisanjem subjekta iz simboličkoga. Na taj način - prijetnjom komadanja tijela ili proždiranjem subjekta - ona postaje neprijateljem simboličkoga poretka: ona je ta, a ne očinska funkcija, koja odlučuje hoće li pripustiti subjekt u svijet društva ili ne. U slikama dijelova tijela koje vještice otkidaju ili se njima naslađuju nazire se odraz zabrinutosti i tjeskobe nad sudbinom vlastita tijela - vještica tako poprima ulogu majke koja prijeti fragmentiranjem tijela. Projekcije i fantazme vezane uz stadij zrcala, a s kojima se subjekt susreće tijekom života u tenzičnim situacijama tako postaju dijelom stalnoga vještičjeg repertoara. Čini se da je u razdoblju najvećih progona moćna majka izazivala više tjeskobe nego li otac. Njegova je uloga svedena tek na potpisnika (simboličkoga) ugovora, glavnog označitelja, no jedino ako subjekt uspije preživjeti djelovanje majke-vještice. 
Iz očuvanih zapisnika doznajemo da je tek jedna žena priznala vlastito kanibalsko iskustvo, Margareta Kuljanka. U njezinu iskazu stoji da je "pojela srca naprijed imenovanoga Celića i njegove žene Marice pošto su ispekle Maričino na dvorištu blizu vratiju, a Mijekovo na imenovanom putu" (Bayer 1982: 616), a osim toga je navela i da je nekom muškarcu "oduzela ruku" (Bayer 1982: 617). Teško je odrediti što je točno motiviralo takvo dramatično priznanje: mislim da je krajnje problematično pripisati ga isključivo torturi jer su i druge žene mučene, no navode tek da znaju ili da su načule o kanibalskim sklonostima drugih vještica, ne i vlastita iskustva. Je li ovdje riječ eventualno o projekciji ili pak o introjekciji, nije nimalo jednostavno nagađati jer nema mnogo podataka. No ono što može poslužiti kao polazišna točka i smjernica u tumačenju jest njezino priznanje da srce Mijeka Celića nije pojela posve sama - podijelila ga je s njegovom majkom i još nekim vješticama. Dakle, predodžba o vještici-kanibalu ovdje je nedvojbeno povezana s majkom koja proždire - onoj Mijeka Celića, možda i s majkom optužene, a možda i s optuženom kao majkom. Iz dijela njezina priznanja u kojem govori o seksualnom odnosu s vragom (koji je mogao biti njezin suprug, ali i neki drugi muškarac) nazire se da je vjerovala kako je za taj odnos bila kažnjena neplodnošću:

Vrag je dolazio k njoj po noći u spodobi njenog gospodara i u odijelu sličnom njegovome, više puta i po dvaput na noć, i na dan mlade večeri, napastujući je da će joj biti bolji nego njezin gospodar, samo neka ide u drugarstvo s vješticama. I otkako ju je to vrag napastovao, u spomenutoj spodobi njenog gospodara - bilo je to pred neko 12 godina - odonda nije više rodila djece. Vrag joj se predstavio kao Matić. (Bayer 1982: 615-616)

Žena koja ne može rađati je prema tome anti-majka, ona koja jede svoju djecu, čak i nerođenu - općenje s vragom (koji je označitelj) zamijenjeno je u ovome slučaju drugim označiteljem - neplodnošću. Margareta Kuljanka je očito vjerovala da je kažnjena za pretjerani jouissance, višak užitka. Dok je kod žena koje govore o antropofagijskim sklonostima drugih vještica vjerojatno riječ o projekcijama, to jest slikama koje izviru iz imaginarnoga i s njime povezanoga odnosa prema tijelu, kada vještica govori o vlastitu iskustvu jedenja ljudskoga mesa i organa vjerojatnije se radi o introjekciji ili pountarnjivanju. Premda su Sándor Ferenczi, tvorac pojma, i sam Freud introjekciju simetrično suprotstavljali projekciji, Lacan se s time ne slaže i tvrdi kako je projekcija imaginarni fenomen i odnosi se na slike, dok je introjekcija povezana sa simboličkim registrom. U procesu introjiciranja uvijek se radi o govoru, jeziku Drugog, odnosno prihvaća se označitelj simboličkoga. Introjekcija se tako odnosi na simboličku identifikaciju, odnosno na nastanak ideal-ja pri završetku procesa edipacije. Nije neobično da su neke od 
optuženih žena introjicirale takve ljudožderske predodžbe: sve su te slike - o vještici koja ubija, uništava ljude, djecu, životinje i hranu - već dugo bile sastavnim dijelom kulture i društva ranoga novog vijeka i dio stanovništva ih je vjerojatno prevodio u neke vlastite kategorije i grijehe. Propovijedi, optužnice, suđenja, govorkanja, priče i predaje sve su utemeljene u jeziku, odnosno jesu jezik i nesvjesno - prihvaćanje nekoga zajedničkoga označitelja ili zamjena jednog označitelja za drugi dijelom su procesa ulaska subjekta u samo društvo, njegovo pozicioniranje unutar simboličkoga.

Dok prijetnje fragmentiranim, raskomadanim tijelom, slike proždiranja ili raspadanja tijela upućuju na svojevrsnu uhvaćenost subjekta u imaginarnome i povezane su s majkom kao prvim Drugim te tjeskobama koje izviru iz tog odnosa, introjiciranje predodžbe o vještici-kanibalu govori o subjektu koji prihvaća označitelja društva u kojem živi, a koje je u ovome slučaju nastojalo strogo nadzirati užitak u tjelesnosti.

Što se tiče infanticida, koji gotovo izravno upućuje na predodžbu vještice kao anti-majke, u većini narativa ostaje ponešto skriven i nazire se iza priča o spravljanju "masti" uz pomoć koje su vještice letjele. U drugim europskim zemljama infanticid kao motiv javlja se s prvim opisima vještičjega sabata u 15. stoljeću, i to u nekoliko varijanti: ubijena djeca su skuhana, od njih je načinjena mast, a ostaci su pojedeni, ili pak - djeca su zadavljena, a sljedeće noći ih vještice otkopavaju iz njihovih grobova te ih odnose na sabat gdje ih kuhaju i jedu. Takve zastrašujuće prizore moglo se pronaći u optužnicama, ponekim iskazima, ali i u vizualnim prikazima vještičjega sabata i nakon što su neki od elemenata iščezli iz optužbi, poput antropofagije, koja se od 16. stoljeća gotovo uopće više ne spominje. Dakako, nijedan od tih motiva nije nov: opisi ritualnih umorstava, pa i ritualnih umorstava djece, javljali su se u optužbama Sirijaca protiv židova, Rimljana protiv kršćana, kršćana protiv gnostika, pa i srednjovjekovne Crkve protiv židova i heretika, no u optužbama za vještičarenje pojavljivali su se gotovo isključivo povezani sa ženama ${ }^{21}$ (Di

${ }^{21}$ Djeca su tijekom progona vještica imala različite uloge, od žrtava do optužitelja pa onda i optuženih za vještičarstvo. U počecima masovnoga lova tijekom 15. i 16. stoljeća djeca su bila žrtvama i to na tri načina: uglavnom na području Umbrije infanticid je bio povezan s vampirizmom - vještice su u obliku golemih kukaca sisale krv djeci; istodobno su na švicarskim sabatima bili žrtvama kanibalističkih rituala, a treći je oblik bilo ubijanje djece uz pomoć kletvi i magije, tj. maleficija, ali bez vampirizma i kanibalizma (Monter 2006: 183-184). Tijekom 17. stoljeća jedino je posljednji način ubijanja djece - maleficijem - ostao prisutan u optužbama. Podjednako zanimljiv dio predodžbi o vješticama koji nudi mogućnost psihoanalitičke interpretacije jest i trenutak kada djeca nisu više samo žrtve nego postaju i onima koji imaju određenu moć. Naime, početkom 16. stoljeća zabilježeni su slučajevi u kojima su djeca odigrala ključnu ulogu u prokazivanju lokalnih vještica, prvo u Baskiji 1525. kada su dvije djevojčice imenovale četrdesetak žena kao vještice, koje su ubrzo i pogubljene. Slični procesi vođeni su kasnije i u drugim dijelovima Europe: u Njemačkoj (Trier, Augsburg, Ellwangen), Francuskoj (istočna Francuska, pokrajina Lorraine), Engleskoj, Škotskoj, Švedskoj i drugdje. Gotovo egzemplaran slučaj matricida i patricida dogodio se 1539., također u Baskiji, kada su jedna devetogodišnjakinja i njezina godinu starija sestra optužile vlastite roditelje za vještičarstvo, i vrlo sličan no mnogo većih razmjera u Švedskoj, kada su stotine djece svjedočile da su ih roditelji ili susjedi vodili na sabat u Blåkullu. Promjene u pravnome sustavu oko 1600. 
Simplicio 2006: 549). U nekome su se trenutku gotovo izjednačile predodžbe o vješticama kao onima koje ubijaju (i to vrlo često djecu) sa samim infanticidom, tako da je većina optužbi za ubojstvo djeteta automatski potpadala pod mnogo širi zločin vještičarenja. Kako tvrdi Di Simplicio, u Europi je tijekom 16. stoljeća započelo drakonsko kažnjavanje infanticida, što je tada i uneseno u kazneno-pravne propise pa je tako u Francuskoj kažnjeno gotovo pet tisuća žena zbog toga zločina, dakle više nego za sam zločin vještičarenja (Soman 1992, prema Di Simplicio 2006: 549). Kako je vjerovanje u vještice i njihove opačine slabjelo, nestajalo je i preklapanje tih dvaju zločina pa su žene kasnije procesuirane isključivo zbog infanticida (Levack 1999: 78-80).

U hrvatskim procesima nije bilo mnogo izravnih optužbi za umorstva djece, a infanticid i kanibalizam izrijekom spominje samo Margareta Dumbović-Boljanec:

Isto tako izjavljuje da je Jalžunka, žena Ključarićeva, vještica i da je kuhala i pripravljala dječju glavu. To je ona vidjela kada je s drugim ortakinjama mimo nje letjela; ali kaže da nije jela te dječje glave. (Bayer 1982: 598)

Premda je noćnome letu (za koji su trebale mast) kao posebnom obilježju/ sposobnosti vještičjega tijela posvećeno više pozornosti tijekom ispitivanja optuženih žena, teško je ne zamijetiti da žene pripovijedaju o načinima njezina spravljanja s mnogo detalja.

Iz iskaza Kate Tinodi doznajemo da

[k]ad (vještice hoće) da prave mast, onda paraju djecu. U kolijevci je guše pa ih skuhaju i iz toga prave mast. A i drugdje gdje ih mogu ugrabiti, na raskršću ili ma gdje. I veli da onom vodom u kojoj se dijete kuha škrope po polju i po vinogradim, i od toga moraju propasti. Kada, veli, sve zajedno ugrabe dijete, onda sve međusobno dijele mast; ako ga pak samo jedna uzme, onda drugima ne da. (Bayer 1982: 574)

Dakako, ona nije priznala da posjeduje masti, to jest nije željela priznati ubojstvo djece, nego je optužila "staru Muhonku" da ih spravlja i da je isključivo u njezinu posjedu.

I optužena Kata Kozjak u procesu iz 1699. ponavlja slično:

kada se spušta dobna granica osoba koje mogu biti optužene, omogućuju i treću fazu involviranosti djece u progonima - ovaj put kao optuženih. Wolfgang Behringer navodi da je znatan dio optuženih krajem 17. i početkom 18. stoljeća otpadao na djecu - posljednji slučajevi zabilježeni su u Bavarskoj 1754. i 1756. kada su na smrt osuđene djevojčice od četrnaest godina (Behringer 1989: 39, prema Monter 2006: 185). U Hrvatskoj postoji podatak za tek jedno, i to petogodišnje dijete (dapače, djevojčicu) koje je osuđeno za vještičarstvo, dok podataka da bi maloljetnici prokazivali roditelje ili susjede nema. Svi ti podaci upućuju, između ostaloga, na kompleksne obiteljske odnose koji su mogli biti pozadinom predodžbi o vješticama, kao i na nedovršene faze edipacije, tj. zaglavljenosti u određenom vremenu subjektivizacije. 
Nadalje veli da su je vještice mazale i da ju je Sabolica mazala, a da ona nema masti. Kaže da mast kuhaju i da u materinoj utrobi dijete umore i uzmu, pa ga kuhaju i iz onoga mast naprave na raskršću. I veli da je ona jedanput bila na raskršću kad su mast pravile. Ono da je bilo dijete postolarke Siverke. To da je bilo oko prošlog Božića. (Bayer 1982: 576)

Taj je podatak - čije su dijete vještice umorile - iznimno rijedak tijekom velikih progona jer uopće nije bio predmetom zanimanja sudskih istražitelja. Iako proizvodnja masti počiva na ideji o prethodno ubijenoj a potom i skuhanoj djeci, čini se da hrvatski sudovi tome nisu pridavali gotovo nimalo pozornosti - na ispitivanjima vještica uopće se ne postavlja pitanje o tome koja su djeca umorena, što jest donekle neobično za prilično malenu i zatvorenu gradsku sredinu kakav je bio Gradec toga doba. Službenih podataka o smrtnosti djece ili broju umrlih iz toga razdoblja nema, kao ni podataka o suđenjima za umorstva djece. Iz toga bi se dalo naslutiti da ili infanticid ipak nije bio tako čest kako bi se moglo pretpostaviti iz količine pronađene masti, ili da se nije smatrao osobito važnim u usporedbi s (preuranjenom) smrću odrasle osobe. Dakako, postoji i treća mogućnost - da je infanticid bio toliko prepleten i povezan s cjelokupnom konstrukcijom, odnosno predodžbom vještičarenja i samih vještica kao anti-majki da se jednostavno nije razmatrao kao zaseban zločin.

Ako su žene u dokumentima, povijesti grada ili književnosti s kraja 17. stoljeća bile nevidljive ili rijetko vidljive, onda su djeca bila zapravo nepostojeća, osim onih koji su pohađali neku od gradečkih škola. O odnosu prema djeci i obiteljskome kontekstu ne doznajemo ništa, tek je iz ponekih zapisnika moguće razabrati da djeca uglavnom nisu smatrana osobito važnim članovima vlastitih obitelji i samoga društva. Tako Kata Kozjak navodi da su djeca o kojoj roditelji, ponajprije majke dostatno ne skrbe izloženija napadima vještica: "I veli da onu djecu koju roditelji proklinju ili koju kamo šalju, po ulicama ili kamo drugdje, najbolje i najbrže uzmu i naškode im" (Bayer 1982: 5809) - moguće je da nestanak djeteta takva obitelj i ne bi smatrala osobito važnim.

I Ana Sirkovica navodi neke detalje kako se spravlja mast ("iz dječjih jetara"), koju ona, dakako, nema, ali zato prokazuje svoje družbenice koje je imaju - ona na taj način nastoji dokazati da nije anti-majka. Tek jedna optužena žena na počecima masovnih progona potkraj 17. stoljeća iznosi drukčiju recepturu te uopće ne spominje djecu kao glavni sastojak, nego “drač, žito i voće". Ta je promjena vidljiva i u zapisnicima sa suđenja iz 18. stoljeća, koji upućuju da je došlo do stanovitih promjena u poimanju zločina i predodžbama vještica. Naime, o masti se rijetko govori i ispituje, a kada se i spominje, naglasak više nije na njezinu glavnome sastojku - djeci, nego se 
ona spravlja od nekih drugih, najčešće neimenovanih sastojaka, i uglavnom više ne služi za noćne odlaske na sabat letom, nego za čaranje ili liječenje.

Optužbe za smrt djece sada postaju direktne, a iznose ih njihovi roditelji ili susjedi, dok je uzrok smrti tijekom 18. stoljeća maleficij. Osim toga, javlja se i u 17. stoljeću razmjerno slabo zastupljena predodžba o vještici kao ženi koja ima moć i iscjeljivanja, a ne samo ubijanja. Sama činjenica da nekoga može izliječiti tereti je kao vješticu jednako kao i činjenica da nekoga može lišiti života bacanjem čini. Optuženoj Bari Petruševki nimalo ne ide u korist što je pomogla djetetu na koje je navodno prethodno bacila čini te je dijete nekoliko dana bolovalo i imalo noćne more:

Kad je tako to dijete jedno tri dana ležalo, išla je ta Bara jednom kroz selo mimo kuće svjedokove. I kad ju je to bolesno dijete čulo gdje govori, izvuklo se do prozora i počelo je toj Bari spočitavati zašto ga već tri noći gnjete. Čuvši to svjedok, počeo je prijetiti toj Bari da će je gospodi tužiti, zar je ona takva žena. Na to je Bara Petruševka odgovorila: "Boga mi, nije to ništa, dijete bulazni; neka se prekriži, neće mu do sutra ništa biti." I kad tamo, dijete je odmah ujutro zdravo ustalo, a prije je kao mrtvo ležalo. (Bayer 1982: 660)

Njezina sposobnost da nekoga učini bolesnim ili pak zdravim podjednako je zastrašujuća jer ona raspolaže moćima nedostupnima običnim ljudima te briše granicu razdvajanja života i smrti, odnosno između subjekta i ništavila. Njezin je slučaj izrazito zanimljiv iz nekoliko razloga, a jedan od njih je i ukupan broj ljudi (djece i odraslih) koje je što izliječila, a što ubila. Osim indirektnih optužbi za infanticid i antropofagiju u 17. stoljeću, dotadašnji procesi gotovo da i ne spominju ljudske žrtve vještica pa stoga optužba protiv Bare Petruševke donekle odudara od drugih procesa - nju se optužilo da je maleficijem ubila ukupno šestero ljudi, od toga četvero djece: Mikca Mihana, jedno neimenovano dijete, svoje unuke, tj. dvoje djece vlastita sina te njegovu ženu, kao i još jedno dijete, sina Bare Petrušićke, a čarolijama da je izliječila jedno neimenovano dijete, Ivana Farkaša, plemića Dizmuša Jelačića (inače sina barunice Jelačić na čijem je posjedu radila) te kmeta Petra Petrušu. Naravno, one koje je izliječila prvo je učinila bolesnima čaranjem. Ni u jednom sačuvanom procesu protiv vještica u Hrvatskoj nitko nije bio terećen za toliko umorstava ni prije ni poslije Petruševke - obično bi osoba bila optužena za jedno umorstvo, rijetko više od toga, a koje bi bilo tek dijelom elaboriranije predodžbe o vješticama, tek jedan u nizu počinjenih zločina. Njezin je slučaj utoliko egzemplaran jer ukazuje na mehanizam konstruiranja čudovišne Drugosti - anti-žene i anti-majke - unutar cijele zajednice, posjeda Lović, Mihovilići i Vivodina u okolici Ozlja sredinom 18. stoljeća. Ovdje gotovo da i nema optužbi koje bi se ticale usjeva ili hrane koje je vještica uništila, tek jedna epizoda sa susjedovom kravom koja je prestala davati mlijeko, i premda 
nitko od svjedoka nije iznio takve sumnje, u optužnici su svejedno pobrojani svi elementi klasične konstrukcije vještica:

[...] sklopivši ugovor s đavlom i uvrstivši se u družbu vještica, raznim je putevima i na nedozvoljene načine svojim čarobnjačkim umijećima škodila ljudima, oranicama, poljima, vinogradima, blagu, stoci i ostalim stvorenjima, tuču pravila i druge štete uzrokovala, štaviše - puteno se pomiješala s đavlom, otkazala bogu dužnu vjeru i druga zlodjela vršila [...]. (Bayer 1982: 668)

Iz tako sročenoga teksta posve je razvidna diskrepancija između sudskoga diskursa, odnosno pravnoga i teološkoga poimanja vještica te predodžbe o vješticama koja je dolazila od puka - one su se mogle preklapati, kao što je donekle vidljivo iz masovnih procesa krajem 17. stoljeća, ali i nisu. ${ }^{22}$ Ipak, većina procesa iz 18. stoljeća omogućuje dublji uvid u psihičke strukture upravo zbog detaljnosti sačuvanih zapisnika i zbog činjenice da iskazi svjedoka nisu dani pod prisilom, za razliku od iskaza optuženih, pa samim time nisu morali biti uklopljeni u standardni demonološki diskurs. Takvi iskazi nam pružaju nešto nijansiraniju sliku vjerovanja u vještice koja su u nekoj mjeri ipak različita od teološko-pravne konstrukcije.

No, osim dotad nezabilježeno mnogo optužbi za umorstva, i to ponajprije djece, te "sudskoga dodatka" koji nije bio utemeljen na iskazima svjedoka, slučaj Bare Petruševke smatram paradigmatskim za načine konstruiranja monstruozne žene/vještice kao anti-majke i koji istodobno upućuje na mehanizme unutar zajednice kojima se prihvaća i dijeli ta Drugost.

Njezino je suđenje jedino poznato u Hrvatskoj na kojem je sin svjedočio protiv vlastite majke i koji je povrh toga bio glavnim pokretačem glasina o svojoj majci kao vještici. Taj podatak saznajemo iz optuženičina svjedočenja pred sudom:

[...] i da nikad nije bilo o njoj toga glasa da bi bila vještica, sve dok nije njezin sin Ivić o njoj (to) razglasio pred kojih dvanaest godina; poslije, otkako je to sin razglasio, kad (je) koga zadesila kakva bolest ili nevolja, na nju su krivnju svaljivali. (Bayer 1982: 672)

\footnotetext{
${ }^{22}$ Slučajevi iz 1699. i slučajevi iz 18. stoljeća prilično se razlikuju u nekim segmentima. Naime, svi sačuvani spisi suđenja s kraja 17. stoljeća upućuju da se radilo o lančanim procesima u kojima je bilo dovoljno da jedna vještica "izda” svoje družbenice kako bi se pokrenula nova suđenja. U tim procesima ili nije bilo iskaza svjedoka ili oni nisu sačuvani pa je nemoguće odrediti za što pojedinu ženu tereti njezina zajednica ili pojedinci, a što je dodano iz "općega imaginarija” koji potječe iz teološko-pravnoga određenja. Zapisnici iz 18. stoljeća pokazuju drukčiji način pokretanja procesa koji više nisu nužno masovni te su sačuvani prilično detaljni iskazi svjedoka, odnosno svih onih koji određenu osobu smatraju vješticom, ili što je iznimno rijetko - vješcem. Suđenja u 18. stoljeću i dalje se temelje na osnovnome zločinu - ugovoru s đavlom - dok je ostatak optužnice najčešće vrlo specifičan i individualan te ne uključuje sve aspekte vještičarstva, osim navedenoga slučaja Petruševke. Utoliko su osamnaestostoljetni slučajevi prikladniji za psihoanalitičke interpretacije jer su u središtu iskazi individualnih, pojedinačnih subjekata (i tužitelja i svjedoka i optuženih).
} 
Na pitanje zašto ju je sin imenovao vješticom odgovara:

Ona je, kad je bila bolesna, otkrila svomu sinu Iviću da imade u ladici nešto novaca, a sin je njezin uzeo ključeve od ladice i pokrao joj novce. Krađu tih novaca nije primijetila dok nisu na Petrovo išli zajedno na sajam. Tamo je po jednoj desetici, koju je on na sajmu izdao, opazila počinjenu sinovljevu krađu. Sin se zatim bio razbolio pa je na to nju potvorio da mu je (to) ona učinila, i tim je putem razglasio kao vješticu. (Bayer 1982: 672)

Dakle, napeti su odnosi nastali u trenutku kada je majka shvatila da je sin, unatoč njezinoj molbi da ne otvara ladicu s novcem prije njezine smrti, ipak to učinio i nešto uzeo za sebe. Kada mu majka nije ništa prigovorila nakon što je krađa otkrivena, Ivan Petruša se iznenada razbolio.

Freud i Lacan bi vjerojatno imali mnogo što za reći o sinovom kršenju zabrane i otvaranju dobro zaključane i tajne majčine ladice u kojoj je skriveno blago koje on otuđuje, što ga odvodi u bolest. Već je na prvi pogled vidljivo da cijela priča čak i suviše poziva na psihoanalitičko tumačenje prema kojem bi sin morao biti na neki način (samo)kažnjen zbog posezanja za nečime što pripada isključivo majci - ponovno se nameće pitanje žudnje i inter- te intra-personalnih odnosa koji se oko nje grade. Majčino uskraćivanje onoga što misli da mu po pravu pripada (ovdje novca) zaziva jednu od prvih djetetovih trauma kada shvaća da nije isključivim predmetom majčina interesa i ljubavi. ${ }^{23}$ Zabrane koje stoje na granici između imaginarnoga i simboličkoga, zabrane koje donosi otac i nameće ih odnosu majka - dijete, ne smije se kršiti jer se takvi prekršaji strogo kažnjavaju - izopćenjem iz zajednice, bolešću ili smrću.

Do toga se trenutka - krađe novca - priče iz perspektive majke i iz perspektive sina podudaraju, no on potom iznosi neke nove detalje i optužuje majku da mu je prijetila i začarala ga:

[...] te je jedva kući došao i ondje na smrt obolio. Kako su pak druga družina i stričevi svjedokovi znali da mu je mati zbog novaca prijetila, išli su odmah k pokojnomu starome gospodinu Vojnoviću [vlasniku posjeda na kojem su oboje radili, op. a.] tužiti mater svjedokovu da je opčinila sina, poginut će, ne skine mu li čine. Onda je došla zapovijed od pokojnoga gospodina, ako sa sina ne skine čine da će je poslati u Zagreb u zatvor. I odmah je svjedok ozdravio, a

${ }^{23}$ Lacan u jednom od ranijih radova, Les complexes familiaux dans la formation de l'individu iz 1938., navodi tri temeljna kompleksa u formiranju subjekta: kompleks odvajanja od majčine dojke, kompleks nametanja i Edipov kompleks. Prvi kompleks, koji Lacan kasnije gotovo da više ni ne spominje, organiziran je oko odnosa majke i djeteta te razvoj složenih odnosa koji u konačnici rezultiraju otuđujućim poistovjećivanjem koje izaziva strah i anksioznost. Premda ne osobito razrađen kod Lacana, mnogi ga smatraju osobito važnim za psihološki razvoj djeteta te kasniju pojavu Edipova kompleksa (usp. Durić 2013: 161-163). 
materi je morao dati novac [...]. I odonda se ne može više nikad njegova mati s njim slagati niti ga trpjeti. (Bayer 1982: 666)

Sin je vlastitu bolest zbog kršenja majčine zabrane doživio kao osvetu majkevještice, u čemu vjerojatno nije bio usamljen tijekom ranoga novoga vijeka, pa ni u hrvatskim procesima nikako nije jedini koji se razbolio - gotovo svaka bolest, bila ona somatizacija nekoga unutarnjega sukoba ili ne, doživljavana je kao čarobnjačko zlodjelo.

Iako to ne spominje izrijekom, čini se da je Ivan Petruša mnogo prije bolesti smatrao svoju majku opasnom, a njihov je odnos bio obilježen sukobima. Osim što je smatrao da ga je majka htjela ubiti, bio je posve uvjeren da je ona doista ubila njegovo dvoje djece te prvu suprugu:

Kako nije mogao te svoje matere više trpjeti, da se morao - ovo je sada druga godina tome - odijeliti od nje, budući da je pretrpio dosta neprilika i progona od svoje matere. Među ostalim izjavljuje da je imao dvoje dječice već za pašu (blaga). Za jedno od njih više puta je mati molila da bi joj ga dao. Ali, jer je bilo njemu potrebno, nije ga htio dati. Kadli ljetos pred Svijećnicom, u subotu navečer, svjedok je legao na svoju postelju i jedno dijete kraj njega. I svjedok je čuo i vidio da je u neko doba noći po tri puta došla mati njegova s gorućom luči nad njega i nad to dijete, i tu je goruću luč na to dijete bacila ne rekavši ništa. Svjedok pak, akoprem je čuo i vidio, nije mogao reći materi ni riječi. Ali smjesta onu je noć ono dijete oboljelo i u ponedjeljak ujutro već je bilo mrtvo. Drugo je pak dijete pred pokladnim utorkom u subotu navečer spopala nekakva zima; i na pokladni je utorak već bilo mrtvo. Obadvoje djece bilo je posve crno kao stari lonac. (Bayer 1982: 666)

Konstrukcija vještice kao anti-majke, kao što je vidljivo iz ovoga ulomka, nije bila povezana samo s činom rađanja ili skrbi o novorođenčadi, što su detaljno prikazale Lyndal Roper i Diane Purkiss u njemačkim i engleskim procesima, nego se strah od uništenja koji predstavlja vještica proteže i kasnije tijekom subjektova života, a prenosi se i dalje pa subjekt strepi i nad mogućom osvetom nad vlastitom djecom, čak i kada njegova majka odavna nije među živima. Kako Petruševka nije mogla nauditi svome sinu, ubila je njegovu djecu koju joj on nije htio predati - bilo mu je posve jasno da je to majčino zlodjelo jer ju je po noći jasno vidio i pritom nije mogao izgovoriti ni riječ. Takav se subjektov iskaz može tumačiti kao noćna mora ili pak fantazma o osvetničkoj, svemoćnoj, proždirućoj majci kojoj se dijete ne može suprotstaviti a niti pobjeći pred njezinom srdžbom.

Kako je već napomenuto, dijada majka - dijete nije idiličan odnos koji je $\mathrm{u}$ domeni prirode sve dok se ne pojavi otac koji provodi dijete $\mathrm{u}$ domenu civilizacije i kulture, u simboličko, pri čemu je on negativac koji narušava ljubav i sklad prvotnoga para. U Lacanovoj interpretaciji Edipova komplek- 
sa uloge su zamijenjene - majka je negativac koji, kada bi dijete ostalo $\mathrm{u}$ njezinim čeljustima (Lacan uspoređuje majku s krokodilom), nikada ne bi dopustila djetetovo ostvarivanje vlastita subjektiviteta, a otac je taj koji ima prvenstveno obrambenu ulogu te čuva dijete od majčine zlokobnosti.

Jednako kao što razlikuje realnoga, imaginarnog i simboličkog oca, Lacan uvodi razliku i između realne, imaginarne i simboličke majke. Pritom je realna majka stvarna, fizički prisutna osoba koja brine o djetetovim potrebama i zahtjevima - za hranom, ljubavlju itd. Simbolička majka je u središtu pozornosti psihoanalize, kako naglašava Evans, ponajprije njezina uloga primordijalnoga Drugog: majka kao takva uvijek je prvo simbolička, a realna postaje kada subjektu uskraćuje njegove zahtjeve (Evans 1996: 118-119). No postoji i imaginarna majka koja je svojevrsna konstrukcija, odnosno imago, slika i to najčešće one čudovišne majke. Ta je majka proizvod djetetove mašte - ili prije, njegovih strahova - i nije nužno stvarna osoba, dapače kao što je vidljivo iz primjera Petruševke i njezina sina - ona može biti i fantastičnim bićem, vješticom. Uporište za takvu konstrukciju subjekt pronalazi u različitim kulturnim predodžbama majke koje su promjenjive, od majke-kanibala, majke-djecoubojice, vještice do milosrdne, požrtvovne i brižne majke. U svijetu preplavljenom vješticama koje ubijaju djecu svoje djece posve je jasno koji je imago u nekom trenutku bio dominantan.

Kao krajnji dokaz majčine mržnje i osvetoljubivosti Ivan Petruša navodi i zadnje u nizu ubojstava onih koji su mu najdraži i najbliskiji - prve supruge s kojom je imao djecu:

[K] ad mu je pred dvije godine oboljela imenovana žena, (koju je imao) prije sadanje žene, pa joj je išao tražiti lijeka k ocima kapucinima u Novo Mjesto, da je onda ta pokojna žena njegova, pred svojom materom Jelom Doretićkom, molila mater svjedokovu neka bi joj odčinila onu nevolju koju joj je, sigurno, ona učinila. Na to je, pred tom Jelom Doretićkom, mati svjedokova rekla toj pokojnoj snasi: "Vrati ti prije svitice moga mlađega sina, jer si ih sigurno ti uzela." [...] I tako je za dva dana umrla ta pokojna žena svjedokova. (Bayer 1982: 667)

Jednako kao i u slučaju krađe novca, i ovu krađu Bara Petruševka strogo je kaznila - pokazala se opasnom i po život pogubnom za vlastitu snahu, odnosno njezin sin sve te smrti tumači kao osvetu usmjerenu protiv njega. Zla majka iz stadija zrcala nije opasna po život samo jednoga subjekta, u ovome slučaju njezina sina, nego i za sve ostale koji ga okružuju: fantazma o proždirućoj majci zahvaća ne samo subjektovo tijelo, nego i ona koja on smatra donekle svojima, njegovim produžecima, u ovome slučaju njegove djece i žene.

Takva čitanja zapisnika kao individualnih iskaza u kojima se zrcale i osobna i kolektivna Drugost, ponešto različite od onih iz pravnih akata ili 
književnosti ranoga novog vijeka, projicirane u nekoliko temeljnih predodžbi vještice imala su za cilj ukazati na ulogu nesvjesnog u kreiranju vještičjega imaginarija. Vještica kao anti-majka koja uživa u antropofagiji i ne preže pred infanticidom simptom je subjektove psihičke strukture: vještica kao prijeteća majka zauzima poziciju subjektova Drugog i ovjerava ili poništava njegovo postojanje. Ona postaje jamstvom njegova identiteta, ali time i onom koja ima moć nad subjektovim životom: ona je ta koja daje život i uzima ga, prijetnja uništenjem koja djetetu dopire od majke nikada ne nestaje. Ona kao Drugi je dio simboličkoga, ali odnos koje dijete ima s njom je dijadni te tako pripada imaginarnome: majka zauzima rubnu poziciju između dvaju registara, imaginarnoga i simboličkoga, prirode i kulture. Ne pojavi li se otac i intervenira u njihov odnos, preusmjeravajući žudnju na sebe i ne uvede li subjekt u svijet simboličkoga, dakle jezika, društva i zakona, subjektu prijeti psihoza u kojoj je simboličko svedeno na imaginarno.

Slike raskomadanih tijela, kastracije, demaskulacije, mutilacije, vađenja utrobe, srca, krvnih žila, proždiranje i orgijanje nad tijelima - sve su to fantazme koje nastaju u stadiju zrcala, a koje prate subjekt tijekom cijeloga života: često se mogu pronaći u dječjim igrama, ponekad se ukazuju u snu, kao noćne more, kroz njih subjekt prolazi u određenoj fazi psihoanalitičkoga tretmana, a eto, pojavljuju se i kao sastavni dio predodžbi o vješticama. Opisi vještičjih prijetnji tijelu i njezina iživljavanja nad bespomoćnim tijelima njezinih žrtava brojni su i jezoviti te se javljaju podjednako i u predodžbama o vještici kao kanibalu, a posebno u onima o vještici kao prijetećoj majci. Iz svih tih primjera, koji su projekcije ili fantazme subjekta, čini se da su oni koji su optuživali žene za vještičarstvo pokazivali određenu zaglavljenost u imaginarnome, odnosno gotovo cjelokupni vještičji imaginarij upućuje na dominantnu i prijeteću majku te na nedostatak ili na slabu očinsku funkciju. Premda nema mnogo sačuvanih podataka o strukturi stanovništva potkraj 17. stoljeća pa do polovice 18. na Gradecu, a još manje iz okolice Zagreba, iz struktura subjekata koji svjedoče na suđenjima vještica dalo bi se naslutiti da su žene imale stvarnu moć u obitelji - bilo zbog ratova u kojima su uglavnom stradavali muškarci ili zbog njihove odsutnosti kao trgovaca i obrtnika koji su često putovali u druge gradove, ili zbog kakvih drugih razloga. No upravo zbog asimetričnih odnosa moći u obiteljima koja se očitovala u formiranju subjektiviteta kao zastrašenoga slikom prijeteće majke, moguće je govoriti o ranom novom vijeku kao razdoblju matrijarhata, a o progonima vještica kao o pobuni protiv majke koja subjektu priječi ulazak u simboličko.

Vrlo sličan proces strukturiranja subjekta moguće je iščitati i kod žena koje su priznale vlastitu vještičastost: dominantne predodžbe o ženama kao zlim, grješnim, opasnim te sklonim tjelesnim užicima prihvaćale su kao vlastiti zrcalni odraz, slika Drugoga postala je tako kod subjekata propusnih granica vlastitom slikom. U svijetu u kojem je bila nametana predodžba o Blaženoj 
Djevici kao idealnom ja, frustracije i strahovi vezani uz majčinstvo i vlastitu seksualnost morali su biti osobito jaki - stoga je identifikacija s vlastitom, "vještičjom” Drugošću bila mnogo vjerojatnija od one s nedostižnim idealom Božanske Majke, idealom koji je u razdoblju protureformacije postajao sve snažnijim.

Tako su vještice mogle postati kolektivnim Drugim - bilo da se vlastiti identitet gradio u opreci ili strahu od njih, bilo da se s njima poistovjećivalo. No korisnost konstruirane vještičje Drugosti prepoznale su i podržavale gradske te državne vlasti - tijela vještica poslužila su za kanaliziranje tjeskoba, sukoba i nasilja unutar zajednice, ali su postala i medij za konstituiranje društva preko postupaka torture i javnoga spaljivanja. Nekada moćna tijela označena đavlom (kao mogućim ocem), torturom se nastojalo prvo "odznačiti", a potom i porobiti, poniziti, uništiti: discipliniranje i javno kažnjavanje služili su kao opomena, ali i za uspostavljanje dijalektičkoga odnosa gospodara i roba.

\section{NAVEDENA LITERATURA I IZVORI}

Ankarloo, Bengt i Stuart Clark, ur. 1999. Witchcraft and Magic in Europe. Ancient Greece and Rome, 2. Philadephia: University of Pennsylvania Press i London: Athlone Press.

Ankarloo, Bengt i Stuart Clark, ur. 2001. Witchcraft and Magic in Europe. Biblical and Pagan Societies, 1. Philadephia, London: University of Pennsylvania Press, Athlone Press.

Barstow, Anne Llewellyn. 1988. “On Studying Witchcraft as Women's History. A Historiography of the European Witch Persecutions". Journal of Feminist Studies in Religion 4/2: 7-19.

Bayer, Vladimir. 1982 [1953]. Ugovor s đavlom. Procesi protiv čarobnjaka u Evropi, a napose u Hrvatskoj. [3. izdanje]. Zagreb: Zora.

Behringer, Wolfgang. 1997. Witchcraft Persecutions in Bavaria. Popular Magic, Religious Zealotry and Reason of State in Early Modern Europe. Cambridge: Cambridge University Press.

Borch-Jacobsen, Mikkel. 1991. Lacan. The Absolute Master. Stanford: Stanford University Press.

Bowie, Malcolm. 1991. Lacan. Harvard: Harvard University Press.

Chiesa, Lorenzo. 2007. Subjectivity and Otherness. A Philosophical Reading of Lacan. Cambridge, Mass., London: MIT Press.

Cohn, Norman. 1993 [1973]. Europe's Inner Demons The Demonization of Christians in Medieval Christendom. London: Pimlico.

Creed, Barbara. 1993. The Monstruos-Feminine. Film, Feminism, Psychoanalysis. London, New York: Routledge.

Davidson, Jane. 1987. The Witch in Northern European Art, 1470-1750. Freren: Luca.

Di Simplicio, Oscar. 2006. "Infanticide". U Encyclopedia of Withcraft. The Western Tradition, 2, Richard M. Golden, ur. Santa Barbara, Oxford: ABC-Clio, 549-550.

Durić, Dejan. 2013. Uvod u psihoanalizu - od edipske do narcističke kulture. Zagreb: Leykam International. 
Elliot, Anthony. 2012. Uvod u psihoanalitičku teoriju. Zagreb: AGM.

Evans, Dylan. 1996. An Introductory Dictionary of Lacanian Psychoanalysis. London, New York: Routledge.

Iacoboni, Marco. 2012. Zrcaljenje drugih. Nova znanost otkriva kako se povezujemo s ljudima oko sebe. Zagreb: Algoritam.

Kieckhefer, Richard. 1976. European Witch Trials. Their Foundations in Popular and Learned Culture, 1300-1500. Berkeley, Los Angeles: University of California Press.

Kieckhefer, Richard. 2008. "Witch Trials in Medieval Europe". U The Witchcraft Reader [2. izdanje]. Darren Oldrige, ur. London, New York: Routledge, 23-30.

Lacan, Jacques. 1938. "Les complexes familiaux dans la formation de l'individu". Pariz: Navarin.

Lacan, Jacques. 1949. "Le stade du miroir comme formateur de la fonction du Je, telle qu'elle nous est révélée dans l'expérience psychanalytique”. U Lacan 1999: 92-100.

Lacan, Jacques. 1978. Le séminaire - Livre 2: Le Moi dans la théorie de Freud et dans la techique de la psychanalyse (1954-1955). J.-A. Miller, ur. Pariz: Seuil.

Lacan, Jacques. 1983. "Stadijum ogledala kao tvoritelj funkcije Ja kakva nam se otkriva u psihoanalitičkom iskustvu". Spisi (izbor). Beograd: Prosveta, 5-13.

Lacan, Jacques. 1986. Četiri temeljna pojma psihoanalize. Zagreb: Naprijed.

Lacan, Jacques. 1999 [1966]. Écrits I. Pariz: Seuil.

Lacan, Jacques. 1999a [1966]. Écrits II. Pariz: Seuil.

Levack, Brian. 1999. "The Decline and End of Witchcraft Prosecutions". U Witchcraft and Magic in Europe. The Eighteenth and Nineteenth Centuries. Bengt Ankerloo i Stuart Clark, ur. Philadelphia: University of Pennsylvania Press, 1-94.

Levack, Brian P. 2004. The Witchcraft Sourcebook. London, New York: Routledge.

Levack, Brian P. 2006 [1987]. The Witch-Hunt in Early Modern Europe. Harlow: Pearson.

Matijašević, Željka. 2006. Strukturiranje nesvjesnog. Freud i Lacan. Zagreb: AGM.

Maxwell-Stuart, P. G. 2001. Witchcraft in Europe and the New World, 1400-1800. Basingstoke, New York: Palgrave.

Monter, William. 2006. "Children”. U Encyclopedia of Withcraft. The Western Tradition, 1. Richard M. Golden, ur. Santa Barbara, Oxford: ABC-Clio, 183-185.

Novaković, Darko. 1991. “Apulej. Sofist između književnosti, magije i demonologije”. U Apulej. Apologija. Govor u vlastitu obranu, o magiji. Split: Logos, 75-91.

Purkiss, Diane. 1996. The Witch in History. Early Modern and Twentieth-century Representations. London: Routledge.

Quaife, G. R. 1987. Godly Zeal and Furious Rage. The Witch in Early Modern Europe. London, Sydney: Croom Helm.

Roper, Lyndal. 1994. Oedipus and the Devil. Witchcraft, Sexuality and Religion in Early Modern Europe. London, New York: Routledge. [http://dx.doi.org/10.4324/9780203426296]

Roudinesco, Elisabeth. 2003. "The Mirror Stage. An Obliterated Archive". U The Cambridge Companion to Lacan. Jean-Michel Rabaté, ur. Cambridge: Cambridge University Press.

Slapšak, Svetlana. 2013. Antička miturgija. Žene. Beograd: Biblioteka XX vek.

Sullivan, Margaret. 2000. "The Witches of Dürer and Hans Baldung Grien”. Renaissance Quarterly 53: 332-401. [http://dx.doi.org/10.2307/2901872] 
Tallis, Raymond. 1988. Not Saussure. A Critique of Post-Saussurean Literary Theory. New York, London: Palgrave Macmillan.

Verhaeghe, Paul. 2001. "Subject and Body. Lacan's Struggle with the Real". Beyond Gender. From Subject to Drive. New York: Other Press, 65-97.

Voltmer, Rita. 2006. "Witch Hunts". Encyclopedia of Witchcraft. The Western Tradition. Santa Barbara: ABC-Clio, 1209-1214.

Zika, Charles. 2002. "Images of Circe and Discourses of Witchcraft, 1480-1580." Zeitenblicke: Online-Journal für die Geschichtswissenschaften 1/1: 35.

\title{
THE WITCH AS THE ANTI-MOTHER: A PSYCHOANALYTIC INTERPRETATION OF TRIAL RECORDS
}

\begin{abstract}
SUMMARY
The article analyzes the records from witch trials which took place in Northwestern Croatia from the late 17 th century until the mid-18th century, identifying their underlying thorny issue, i.e. the relationship towards the body and physicality. The analysis of trial statements, seen as women's personal narratives about their lives, fears, projections and phantasms, shows that the anxieties related to the manifestations of the body spring from the psychological structure of subjectivity. Certain elements of witch imagery, including infanticide and anthropophagy, indicate the existence of fear of the mother who prevents the subject from entering the space of the symbolic, thus leading to a sort of trappedness in a liminal area between the imaginary and the symbolic. At the end of the 17 th century, the mother as the subject's Other that guarantees his/her life and identity, becomes a monstrous witch threatening to abolish the entire "female" domain - children, home, food, animals, at the same time becoming a collective Other that channels conflicts, anxieties and violence within society.
\end{abstract}

Keywords: witches, innerland Croatia, Lacan, psychoanalytic criticism, the Other, anthropophagy, infanticide, body 